\section{ALTERNATIVE ENERGY SYSTEMS}

\section{by Don Felts}

Alternative energy systems, other than active and passive solar, available to building designers include: wind, biofuels, and photovoltaic solar conversion. These vary in complexity from the simple wood burning stove or fireplace to highly sophisticated large scale wind generators. Utilization of these alternative energy systems requires careful consideration by designers as well as additional capital outlays by the owner and investor.

The hardware and the technology for the implementation of these alternative energy systems are readily available. In some instances, these systems were widely used as energy sources before the advent of cheap fossil fuels. Windmills that pumped water and generated electricity were a common sight throughout rural areas. Hand fired boilers and furnaces that could accommodate a variety of fuels including coal, wood and trash were frequently used. In many instances, this energy hardware was very basic, somewhat inefficient and unreliable. With the advent of precision manufacturing and solid state electronics, reliability has been greatly improved, efficiency somewhat improved.

The rapidly changing economics and finite limits on the availability of fossil fuels are creating new markets for old technologies and new hope for the development and deployment of relatively new technologies such as photovoltaic solar conversion. It is essential that architects and engineers become aware of the alternative energy systems and consider them for use in the buildings they design.

\section{Wind Energy}

Wind is a non-polluting renewable solar energy resource. The potential for energy from the wind varies widely throughout the State of New Mexico (figure 1). The greatest potential is in the high plains of the northeastern part of the state. Other good areas include the plains east of the mountain ranges along the Rio Grande Valley and in southwestern New Mexico. The heavily populated areas of the central Rio Grande Valley have a low potential for wind energy.

Although figure one gives a good indication of wind potential in a given area, local microclimatic conditions that could generate favorable winds should not be overlooked. Geologic formations such as mountain ranges, and canyons provide natural paths for hot air to rise up from lowlands during the day and cold air to drop down from the highlands at night. Canyons and passes also focus low velocity winds, off the flatlands, through smaller areas thus greatly increasing the

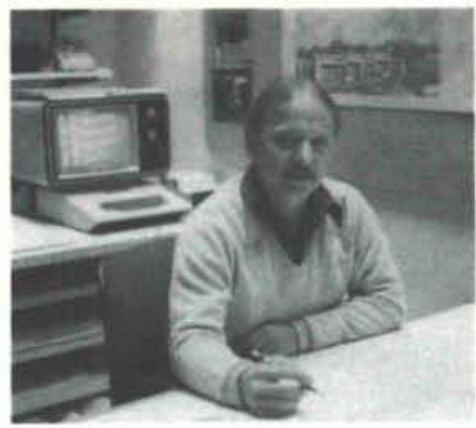

\section{Don Felts, P.E.}

Don Felts is a Registered Professional Engineer and principal owner of Don Felts and Associates, Designers, Engineers, of Albuquerque, New Mexico. His firm offers Mechanical and Electrical consulting services with an emphasis on energy conserving design, passive and active solar systems, natural lighting, and other alternative energy systems.

Felts received a Bachelor of Science degree from the School of Engineering and Technology, Southern Illinois University. Before forming his own firm in 1976, he was a Staff Engineer for a midwestern architectural firm. He has been involved in a wide variety of alternative energy projects.

velocity and the potential for extracting useful energy. A good example of this is the Tijeras Canyon east of Albuquerque.

The power output of a wind generator is directly proportional to the cube of the wind velocity. This is graphically illustrated in Figure 2. In areas with

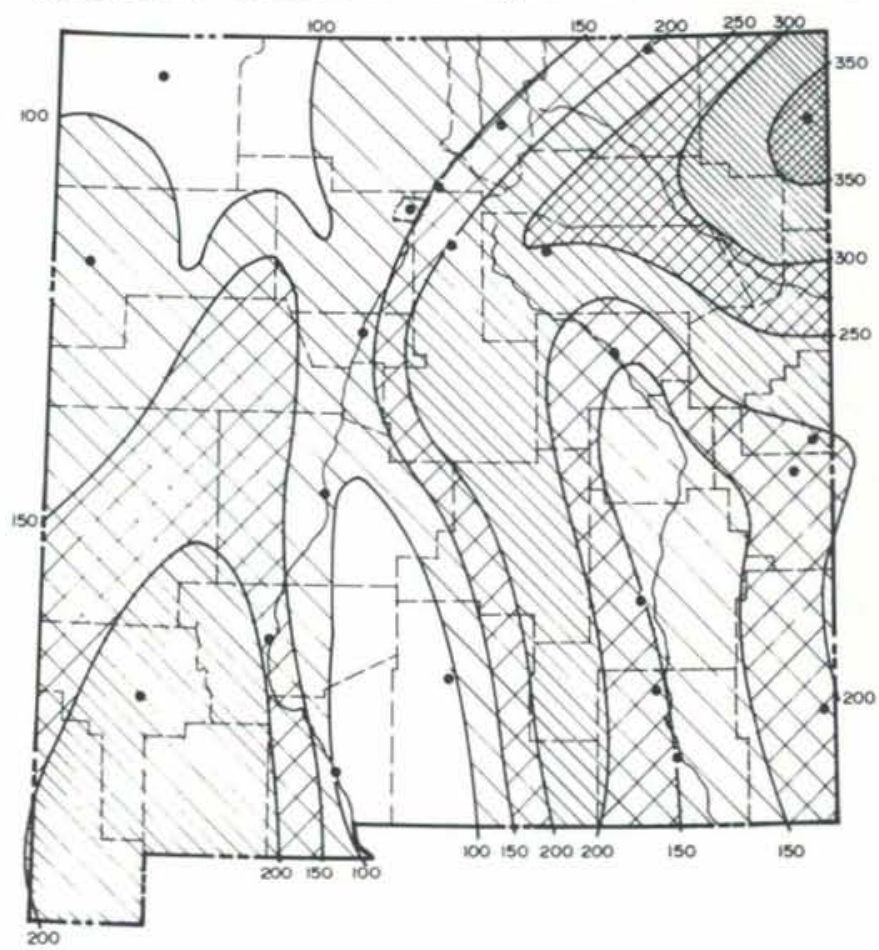

FIGURE 1

TOTAL POWER IN SURFACE WINDS, ANNUAL AVERAGE. IN WATTS PER SQUARE METER, IN FLAT OPEN AREAS FROM "ENERGTTIC NEW MEXICO -.. SECOND EDITION" BY ALBUQUEROUE INDUSTRIAL OEVELOPMENT SERVICE COOPERATIVE AND INDUSTRIAL FOUNDATION OF ALBUQUERQUE, NOVEMBER, 1977 
average wind velocities of $10 \mathrm{mph}$ such as Albuquerque, theoretical wind power densities on the order of 5 watts per square foot can be expected. If the wind speed were increased by $50 \%$ from 10 to $15 \mathrm{mph}$, the theoretical wind power density would increase by over $200 \%$ to over 16 watts per square foot. This fundamental principle is critical to the selection of wind generators as alternative energy sources.

Like all solar energy sources, the wind is intermittent. Therefore, a means must be provided to store the wind's energy for utilization as required by the building's systems and its occupants. A frequently used method is storage batteries. The batteries are charged when the wind is blowing and discharge as required to meet the building load. Disadvantages of this storage and utilization method are the cost of the batteries and the floor space that must be devoted to them. Also, most electrical equipment operates on alternating current. Thus inverters are often required to change direct current from the generator to alternating current for the electrical equipment.

Another method would be to operate the wind generator in parallel with the utility company interface. That is, when excess electricity was being generated by the wind, it could be fed into the utility company grid. When the wind was not meeting the electrical requirements of the building, electricity would be supplied from the utility company grid. Disadvantages of this method include the fact that excess wind energy may not always coincide with the utility company peak demand periods. Thus, the utility company may have no use for the wind energy.

A method that seems to offer a great deal of potential is thermal storage. This method would use the electricity generated by the wind to raise the

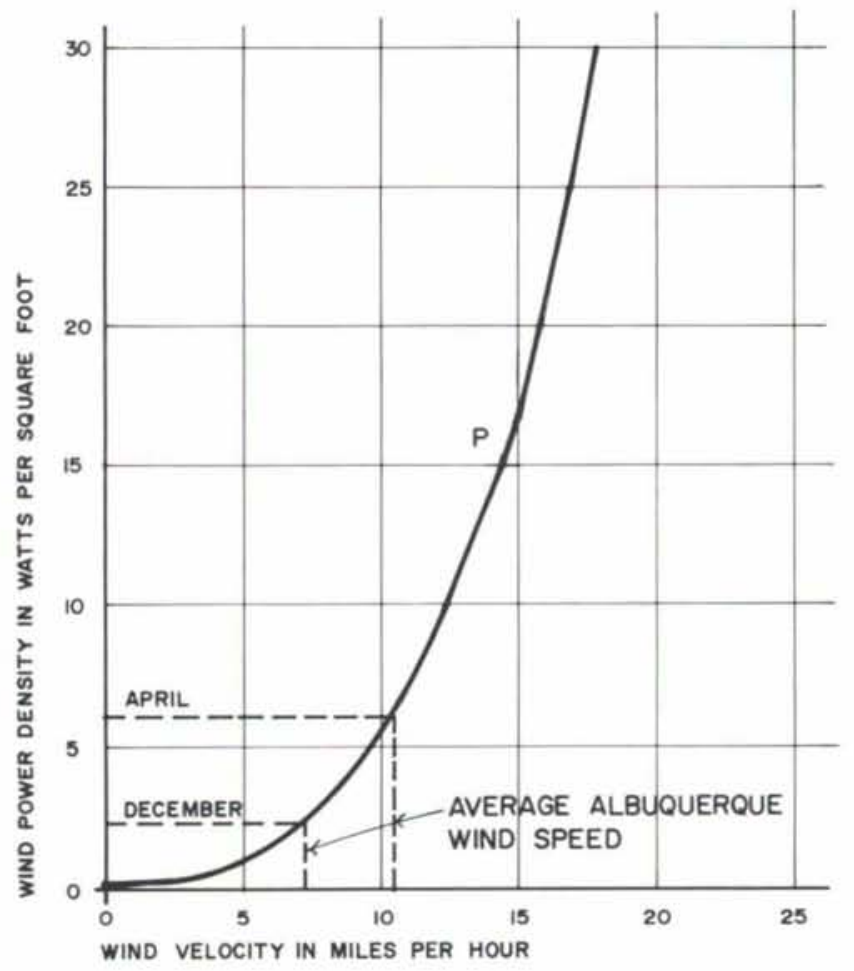

FIGURE 2 temperature of water in a storage tank. The heated water could then be used as a heat sink for water to air heat pumps or fan coil units. It could also be used as domestic hot water. Advantages would include the elimination of expensive batteries and inverters. Also, the thermal storage could be used in conjunction with active and passive solar systems.

Where a public water supply is not available, wind is a viable energy source for pumping water from deep wells. However, in order to maintain adequate pressure at plumbing fixtures, elevated storage tanks from 50 to 60 feet above the fixtures would be required. Since elevated tanks could be quite expensive, an effective compromise might be to use wind energy to pump water to a grade level storage tank. Then, an electric pump and pneumatic pressure tank could be used to maintain pressure in the building's plumbing system.

\section{Biofuels}

Biofuels are renewable solar energy resources obtained essentially from plants. Forms of biofuels that could be readily used as energy sources for building systems include methane, alcohol and wood. Biofuels are labor intensive and tend to have a low net energy output.

Methane gas can be produced on site from domestic sewage and waste. An average adult could contribute $0.25 \mathrm{lbs}$ of volatile solids per day to a methane generator ${ }^{1}$. Each pound of volatile solids could produce as much as 15 cubic feet of methane with a heat content of $850 \mathrm{BTU}$ per cubic foot.

A recent study done for the State of New Mexico's Turquoise Lodge Special Medical Hospital for the Treatment of Alcoholism indicate that the facility's equivalent full time population of 60 people could produce as much as 225 cubic feet of methane gas per day. This would yield enough energy to meet only a very, very small portion of the building's daily energy requirements.

Due to the small yield, on site methane production from domestic waste is probably not feasible. Instances where it might be feasible include buildings where large amounts of organic waste are produced such as food processing industries.

Alcohol fuel has been receiving a great deal of attention in the national press. It is a renewable resource that has the potential of providing a major portion of this nation's energy requirements. Ethanol or grain alcohol not only yields a high grade fuel but also yields a high protein mash that can be fed to cattle.

The Mother Earth News issue number 61 gives a complete description of a low cost $(\$ 500)$ still with a yield of 8 gallons per hour. With a heat content of approximately 90,000 BTU per gallon and a combustion efficiency of $50 \%$, it would require approximately 400 hours of operation of the still to produce enough fuel to meet the space heating requirements of the aforementioned 10,000 square foot, 60 patient Turquoise Lodge Alcoholism Treatment Hospital. 